\title{
LIQUID KIND, TEMPERATURE, MOISTURE, AND AGEING AS AN OPERATING PA- RAMETERS CONDITIONING RELIABILITY OF TRANSFORMER COOLING SYSTEM
}

\section{RODZAJ CIECZY, TEMPERATURA, ZAWILGOCENIE ORAZ ZESTARZENIE JAKO PARAMETRY EKSPLOATACYJNE WARUNKUJĄCE NIEZAWODNOŚĆ UKŁADU CHŁODZENIA TRANSFORMATORA*}

\begin{abstract}
The article presents research results of thermal properties of insulating liquids used in power transformer cooling system. The authors analyzed the influence of such factors, as the kind of the liquid, temperature, moisture and ageing rate of the liquid on thermal properties of the liquids. The analyzed properties of the liquids were thermal conductivity coefficient $\lambda$, kinematic viscosity $v$, density $\rho$, specific heat $\mathrm{cp}$, and thermal expansion factor $\beta$. These properties determine the ability of the liquid to heat transport - heat transfer factor $\alpha$ - what means the properties describe reliability of power transformer cooling system. The authors calculated the factor of heat transfer by the investigated insulating liquids on the basis of measured values of thermal properties.
\end{abstract}

Keywords: power transformers, insulating liquids, heat transfer factor, moisture, ageing.

\begin{abstract}
W artykule przedstawiono wyniki badań właściwości cieplnych cieczy elektroizolacyjnych, wykorzystywanych w uktadzie chłodzenia transformatora wysokiego napięcia. Dokonano analizy wpływu takich czynników jak rodzaj cieczy, temperatura, stopień jej zawilgocenia oraz zestarzenia na właściwości cieplne cieczy. Analizowanymi właściwościami cieczy były przewodność cieplna właściwa $\lambda$, lepkość kinematyczna v, gestość $\rho$, ciepło właściwe cp oraz rozszerzalność cieplna $\beta$. Właściwości te określaja zdolność cieczy do transportu ciepła - wspótczynnik przejmowania ciepła $\alpha$, a tym samym warunkuja niezawodność układu chłodzenia transformatora. Na podstawie zmierzonych przez autorów wartości właściwości cieplnych określony zostat wspótczynnik przejmowania ciepła badanych cieczy elektroizolacyjnych.
\end{abstract}

Słowa kluczowe: transformatory energetyczne, ciecze elektroizolacyjne, współczynnik przejmowania ciepła, zawilgocenie, zestarzenie

\section{Introduction}

Temperature distribution in power transformer plays a crucial role in providing proper work of the transformer [8, 15-17]. Too high temperature results in many negative effects, which can cause threats for the device itself, the maintenance personnel, and the natural environment $[4,5]$. Raised temperature in the transformer affects acceleration of insulating system ageing. The ageing may result in deterioration of many properties of the insulating system, such as resistance drop, increase of dielectric losses $\tan (\delta)$, moisture increase $[6,13,14,22,26]$. The mentioned above results were often a reason of transformer breakdown or destruction in the past [9].

Heat transport in the transformer goes along the following way: heat source $\rightarrow$ paper impregnated with insulating liquid $\rightarrow$ insulating liquid $\rightarrow$ tank $\rightarrow$ air [18]. Thus, the insulating liquid plays an important role in heat transport. This process is connected with the effect of heat transfer by the liquid and it depends on a number of liquid thermal properties, such as thermal conductivity, viscosity, specific heat, density, and thermal expansion.

The insulating liquid changes its ageing and moisture rate and works in wide range of temperature during operation. Investigations of aged and moisture liquid and in various temperature are made mainly for dielectric properties (not for thermal properties). In [3] there are information about the influence of ageing rate of liquid on dielectric properties, such as electric permittivity, dielectric losses $\tan (\delta)$ and dielectric strength. The influence of liquid moisture on its dielectric losses and electric permittivity is described in [25]. However, the influence of temperature on dielectric properties, such as dielectric strength and dielectric losses $\tan (\delta)$, is presented in [23].

There is no information about detailed thermal properties of insulating liquid in literature. There is information regarding to just new liquid (not aged and not moisture) and for chosen value of temperature. Manufacturers of insulating liquid give information concerning to thermal properties for temperature usually not higher than $40^{\circ} \mathrm{C}$ $[1,7,19]$. It is possible to find not complete information regarding to thermal properties of new insulating liquid $[6,21,24]$. However, the influence of temperature only on one from many thermal properties (kinematic viscosity) and only for new insulating liquid is described in [20]. Summarizing, it is possible to say that there is not so many investigations regarding to the influence of ageing and moisture on thermal properties of insulating liquid.

It can be a reason of mistakes during transformer design. Temperature distribution, as a result of computer simulation, which was obtained on the basis of thermal properties just for one value of temperature, can be a sample of the mistakes.

Complete knowledge about thermal properties of liquid for various rates of ageing and moisture, and for various values of tempera-

(*) Tekst artykułu w polskiej wersji językowej dostępny w elektronicznym wydaniu kwartalnika na stronie www.ein.org.pl 
ture, is necessary and will bridge a gap in literature, what is a genesis of the paper.

\section{Aim and range of the investigations}

The influence of kind of liquid, temperature, moisture and ageing on thermal properties of the insulating liquid (thermal conductivity coefficient $\lambda$, kinematic viscosity $v$, density $\rho$, specific heat $c_{p}$, thermal expansion factor $\beta$ ) was the aim of the investigations. These properties describe the ability of the liquid to heat transfer - heat transfer factor $\alpha$. On the basis of thermal properties, measured by authors, the factor $\alpha$ was determined using the following formula:

$$
\alpha=\sqrt[n+1]{c \cdot \lambda^{1-n} \cdot g^{n} \cdot \delta^{3 n-1} \cdot \beta^{n} \cdot \rho^{n} \cdot c_{p}^{n} \cdot v^{-n} \cdot q^{n}}
$$

where: $\alpha$ - heat transfer factor of the liquid $\left[\mathrm{W} \cdot \mathrm{m}^{-2} \cdot \mathrm{K}^{-1}\right], n, c$ - constants dependent on the flow character, temperature and geometry, $\lambda-$ thermal conductivity coefficient $\left[\mathrm{W} \cdot \mathrm{m}^{-1} \cdot \mathrm{K}^{-1}\right]$, $g$ - acceleration of gravity $\left[\mathrm{m} \cdot \mathrm{s}^{-2}\right], \delta-$ characteristic dimension dependent on the flow character $[\mathrm{m}], \beta$ - thermal expansion $\left[\mathrm{K}^{-1}\right], \rho-$ density $\left[\mathrm{g} \cdot \mathrm{l}^{-1}\right], c_{p}-$ specific heat $\left[\mathrm{J} \cdot \mathrm{kg}^{-1} \cdot \mathrm{K}^{-1}\right]$, $v$ - kinematic viscosity $\left[\mathrm{mm}^{2} \cdot \mathrm{s}^{-1}\right], q$ - surface thermal load $\left[\mathrm{W} \cdot \mathrm{m}^{-2}\right]$.

Measurements of the mentioned above thermal properties were taken according to appropriate standards [2, 10-12]. The measurements were done on measurement systems, which in most cases had been designed, built, and tested by the authors.

\section{Measurement results}

\subsection{Influence of a liquid kind on thermal properties of insu- lating liquids}

Table 1 presents measurement results of five thermal properties and calculation results of the heat transfer factor $\alpha$ depending on a kind of insulating liquid. A comparative analysis was added with the assumption that the reference liquid will be mineral oil. This choice was supported by the fact that at present it is the most frequently used insulating liquid in transformers.

Thermal conductivity $\lambda$ of both the esters was much higher than thermal conductivity of mineral oil. Conductivity of synthetic ester was higher than mineral oil conductivity by $18.8 \%$. Conductivity of natural ester was higher than mineral oil conductivity by $36.8 \%$.

Kinematic viscosity $v$ of the esters was much higher than viscosity of the mineral oil. Viscosity of synthetic ester was higher than mineral oil viscosity by $223 \%$. Viscosity of natural ester was higher than mineral oil viscosity by $230 \%$.

Specific heat $c_{p}$ of the esters was higher than specific heat of mineral oil. Specific heat of synthetic ester was higher than specific heat

Table 1. Measurement results of five thermal properties of the liquids and calculation results of the heat transfer factor a depending on a kind of insulating liquid; temperature $T=25^{\circ} \mathrm{C}$, new and dry liquid

\begin{tabular}{l|c|c|c}
\hline \multicolumn{1}{c|}{ Property } & $\begin{array}{c}\text { Mineral } \\
\text { oil }\end{array}$ & $\begin{array}{c}\text { Synthetic } \\
\text { ester }\end{array}$ & $\begin{array}{c}\text { Natural } \\
\text { ester }\end{array}$ \\
\hline Thermal conductivity $\lambda\left[\mathrm{W} \cdot \mathrm{m}^{-1} \cdot \mathrm{K}^{-1}\right]$ & 0.133 & 0.158 & 0.182 \\
Kinematic viscosity $\mathrm{u}\left[\mathrm{mm}^{2} \cdot \mathrm{s}^{-1}\right]$ & 17.08 & 55.14 & 56.29 \\
Specific heat $c_{p}\left[\mathrm{~J} \cdot \mathrm{kg}^{-1} \cdot \mathrm{K}^{-1}\right]$ & 1902 & 1905 & 2028 \\
Density $\rho\left[\mathrm{kg} \cdot \mathrm{m}^{-3}\right]$ & 867 & 964 & 917 \\
Thermal expansion $\beta\left[\mathrm{K}^{-1}\right]$ & 0.00075 & 0.00076 & 0.00074 \\
Heat transfer factor $\mathrm{a}\left[\mathrm{W} \cdot \mathrm{m}^{-2} \cdot \mathrm{K}^{-1}\right]$ & 82.35 & 69.04 & 73.46 \\
\hline \hline
\end{tabular}

of mineral oil by $0.2 \%$. Specific heat of natural ester was higher than specific heat of mineral oil by $6.6 \%$.

Density $\rho$ of the esters was higher than mineral oil density. Density of synthetic ester was higher than mineral oil density by $11.2 \%$. Natural ester density was higher than mineral oil density by $5.8 \%$.

Thermal expansion $\beta$ of the esters was comparable to mineral oil expansion. Thermal expansion of synthetic ester was higher tha mineral oil expansion by $1.1 \%$. Thermal expansion of natural ester was less than mineral oil expansion by $1.1 \%$.

The heat transfer factor $\alpha$ of both esters, calculated on the basis of the mentioned above measurement results, was less than the mineral oil factor. The heat transfer factor of synthetic ester was less than the heat transfer factor of mineral oil by $16.2 \%$. The heat transfer factor of natural ester was less than the heat transfer factor of mineral oil by $10.1 \%$. This means that mineral oil has the best properties of carrying away heat outside of all the studied liquids.

A lower heat transfer factor of synthetic and natural esters, in comparison to mineral oil, was caused by much higher viscosity (by over $200 \%$ ) of the esters. Higher ester viscosity, in comparison to mineral oil viscosity, results from their chemical composition and is connected with substantially larger internal friction forces of the esters. When a liquid is in motion, the neighbouring liquid layers move with different velocities, and acting mutually with internal friction forces. The effect of liquid viscosity can be explained by momentum exchange between the adjacent layers of flowing liquid. This exchange takes place as a result of migrating liquid particles from one layer to the other. The particles that migrate from the layer moving more slowly to the layer moving faster cause a momentum decrease of the faster layer.

\subsection{Influence of temperature on thermal properties of insu- lating liquids}

Table 2 presents measurement results of five thermal properties and calculation results of the heat transfer factor $\alpha$ as a function of insulating liquid temperature. A comparative analysis was done assuming that the reference temperature will be $25^{\circ} \mathrm{C}$.

With temperature increase from $25^{\circ} \mathrm{C}$ to $80^{\circ} \mathrm{C}$, thermal conductivity $\lambda$ of all the kinds of liquids slightly decreased. For mineral oil, thermal conductivity decreased by $5.3 \%$, for synthetic ester by $4.4 \%$, and for natural ester by $3.9 \%$.

Temperature increase also resulted in a considerable drop of kinematic viscosity $v$ independently of a liquid kind. For mineral oil, viscosity decreased by $80 \%$, for synthetic ester by $85 \%$, and for natural ester by $80 \%$.

The temperature increase from $25^{\circ} \mathrm{C}$ to $80^{\circ} \mathrm{C}$ caused an increase of specific heat $c_{p}$ of all the analyzed liquids. For mineral oil, specific heat increased by $15 \%$, for synthetic ester by $13 \%$, and for natural ester by $11 \%$.

With temperature increase, density $\rho$ of all the liquids decreased a little. For mineral oil it was $4.0 \%$, for synthetic ester $3.9 \%$, and for natural ester $4.0 \%$.

The temperature increase from $25^{\circ} \mathrm{C}$ to $80^{\circ} \mathrm{C}$ also caused a slight increase of thermal expansion $\beta$. For mineral oil this increase was $6.7 \%$, for synthetic ester $4.0 \%$, and for natural ester $8.1 \%$.

Temperature increase caused an increase of the heat transfer factor $\alpha$, independently of the liquid kind. This increase was $51 \%$ for mineral oil, $63 \%$ for synthetic ester, and $51 \%$ for natural ester. This means the higher the temperature the better the liquid carries away heat outside.

The heat transfer factor of a liquid was most heavily affected by viscosity, which was caused by a higher temperature. A drop of liquid viscosity, caused by a higher temperature, should be associated with a decrease of attraction forces acting among liquid particles resulting from their kinetic energy. This results in a drop of internal friction forces and viscosity decrease. 
Table 2. Measurement results of five thermal properties and calculation results of the heat transfer factor a as a function of insulating liquid temperature; new and dry liquid

\begin{tabular}{|c|c|c|}
\hline \multirow{2}{*}{ Property } & \multicolumn{2}{|c|}{ Mineral oil } \\
\hline & $25^{\circ} \mathrm{C}$ & $80^{\circ} \mathrm{C}$ \\
\hline Thermal conductivity $\lambda\left[\mathrm{W} \cdot \mathrm{m}^{-1} \cdot \mathrm{K}^{-1}\right]$ & 0.133 & 0.126 \\
\hline Kinematic viscosity $\mathrm{u}\left[\mathrm{mm}^{2} \cdot \mathrm{s}^{-1}\right]$ & 17.08 & 3.43 \\
\hline Specific heat $c_{p}\left[J \cdot \mathrm{kg}^{-1} \cdot \mathrm{K}^{-1}\right]$ & 1902 & 2187 \\
\hline Density $\rho\left[\mathrm{kg} \cdot \mathrm{m}^{-3}\right]$ & 867 & 832 \\
\hline Thermal expansion $\beta\left[\mathrm{K}^{-1}\right]$ & 0.00075 & 0.00080 \\
\hline Heat transfer factor a $\left[\mathrm{W} \cdot \mathrm{m}^{-2} \cdot \mathrm{K}^{-1}\right]$ & 82.35 & 124.67 \\
\hline \multirow{2}{*}{ Property } & \multicolumn{2}{|c|}{ Synthetic ester } \\
\hline & $25^{\circ} \mathrm{C}$ & $80^{\circ} \mathrm{C}$ \\
\hline Thermal conductivity $\lambda\left[\mathrm{W} \cdot \mathrm{m}^{-1} \cdot \mathrm{K}^{-1}\right]$ & 0.158 & 0.151 \\
\hline Kinematic viscosity $\cup\left[\mathrm{mm}^{2} \cdot \mathrm{s}^{-1}\right]$ & 55.14 & 8.11 \\
\hline Specific heat $c_{p}\left[\mathrm{~J} \cdot \mathrm{kg}^{-1} \cdot \mathrm{K}^{-1}\right]$ & 1905 & 2149 \\
\hline Density $\rho\left[\mathrm{kg} \cdot \mathrm{m}^{-3}\right]$ & 964 & 926 \\
\hline Thermal expansion $\beta\left[\mathrm{K}^{-1}\right]$ & 0.00076 & 0.00079 \\
\hline Heat transfer factor $a\left[\mathrm{~W} \cdot \mathrm{m}^{-2} \cdot \mathrm{K}^{-1}\right]$ & 69.04 & 112.24 \\
\hline \multirow{2}{*}{ Property } & \multicolumn{2}{|c|}{ Natural ester } \\
\hline & $25^{\circ} \mathrm{C}$ & $80^{\circ} \mathrm{C}$ \\
\hline Thermal conductivity $\lambda\left[\mathrm{W} \cdot \mathrm{m}^{-1} \cdot \mathrm{K}^{-1}\right]$ & 0.182 & 0.175 \\
\hline Kinematic viscosity $\cup\left[\mathrm{mm}^{2} \cdot \mathrm{s}^{-1}\right]$ & 56.29 & 11.50 \\
\hline Specific heat $c_{p}\left[J \cdot \mathrm{kg}^{-1} \cdot \mathrm{K}^{-1}\right]$ & 2028 & 2259 \\
\hline Density $\rho\left[\mathrm{kg} \cdot \mathrm{m}^{-3}\right]$ & 917 & 880 \\
\hline Thermal expansion $\beta\left[\mathrm{K}^{-1}\right]$ & 0.00074 & 0.00080 \\
\hline Heat transfer factor a $\left[\mathrm{W} \cdot \mathrm{m}^{-2} \cdot \mathrm{K}^{-1}\right]$ & 73.46 & 111.06 \\
\hline
\end{tabular}

\subsection{Moisture influence on thermal properties of insulating liquids}

Table 3 presents measurement results of five thermal properties and calculation results of the heat transfer factor $\alpha$ as a function of insulating liquid moisture. A comparative analysis was done by comparing thermal properties of a moistened and dry liquid.

Preparation of the liquids (both dried and moistened) consisted in drying and moistening samples of mineral oil, synthetic ester, and natural ester in the same conditions. As a result of different water solubility, dry and moistened samples of the particular liquids had different water contents. For dry samples, moisture was 2 ppm for mineral oil, 45 ppm for synthetic ester, and 34 ppm for natural ester. In turn, for moistened samples, moisture was equal to $46 \mathrm{ppm}$ for mineral oil, $1875 \mathrm{ppm}$ for synthetic ester, and $822 \mathrm{ppm}$ for natural ester.

With moisture increase, thermal conductivity $\lambda$ of all the insulating liquids practically remained the same. For mineral oil, conductivity increased slightly by $0.8 \%$ and for the esters it remained at the same level.

Moisture increase resulted in a tenuous drop of liquid kinematic viscosity $v$. Mineral oil viscosity remained at the same level. Synthetic ester viscosity decreased by $3.7 \%$, whereas of natural ester by $2.4 \%$.

Liquid moisture increase brought a certain increase of their specific heat $c_{p}$. Specific heat of mineral oil increased by $6.0 \%$, synthetic ester by $3.7 \%$, and natural ester by $0.8 \%$.

Insulating liquid moisture had no effect on their density $\rho$, which was independent of the liquid kind.

Liquid moisture did not cause any larger changes of thermal expansion $\beta$. The expansion of mineral oil and synthetic ester remained at the same level, whereas for natural ester it decreased by $1.4 \%$.
Moisture increase caused a slight increase of the heat transfer factor $\alpha$, independently of the liquid kind. This increase was $1.1 \%$ for mineral oil, $1.9 \%$ for synthetic ester, and $0.4 \%$ for natural ester. It means the higher moisture the better ability of liquid to heat transfer.

A slight increase of the heat transfer factor of the liquid, caused by its moisture should be linked with specific heat increase. Specific heat of dry insulating liquid is equal to about $2000 \mathrm{~J} \cdot \mathrm{kg}^{-1} \cdot \mathrm{K}^{-1}$, whereas of pure water it is $4190 \mathrm{~J} \cdot \mathrm{kg}^{-1} \cdot \mathrm{K}^{-1}$. This means that insulating liquid moisture resulted in its increase of specific heat $c_{p}$, and its effect was an increase of the heat transfer factor $\alpha$.

\subsection{Influence of ageing on thermal properties of insulating liquids}

Table 4 presents measurement results of five thermal properties and calculation results of the heat transfer factor $\alpha$ as a function of ageing rate of an insulating liquid. A comparative analysis was done by comparing thermal properties of a new and aged liquid.

A new liquid meant that the authors used for the research liquid samples supplied directly from the manufacturer. The acid number was less than $0.010 \mathrm{mg}_{\mathrm{KOH}} \cdot \mathrm{g}^{-1}$ oil for mineral oil, less than 0.030 $\mathrm{mg}_{\mathrm{KOH}} \cdot \mathrm{g}^{-1}$ oil for synthetic ester, and equal to $0.020 \mathrm{mg}_{\mathrm{KOH}} \cdot \mathrm{g}^{-1}$ oil for natural ester.

An aged liquid of all the three kinds meant that the ageing process was progressing in the same conditions. This resulted in a little different values of the acid number for the particular kinds of the liquids. The acid number was equal to $0.135 \mathrm{mg}_{\mathrm{KOH}} \cdot \mathrm{g}^{-1}$ oil for mineral oil, $0.175 \mathrm{mg}_{\mathrm{KOH}} \cdot \mathrm{g}^{-1}$ oil for synthetic ester, and $0.173 \mathrm{mg}_{\mathrm{KOH}} \cdot \mathrm{g}^{-1}$ oil for natural ester.

With an increase of the liquid ageing rate, thermal conductivity $\lambda$ of all the insulating liquids practically remained unchanged. For

Table 3. Measurement results of five thermal properties and calculation results of the heat transfer factor a as a function of insulating liquid moisture; temperature $T=25^{\circ} \mathrm{C}$, new liquid

\begin{tabular}{|c|c|c|}
\hline \multirow{2}{*}{ Property } & \multicolumn{2}{|c|}{ Mineral oil } \\
\hline & dry & moistened \\
\hline Thermal conductivity $\lambda\left[\mathrm{W} \cdot \mathrm{m}^{-1} \cdot \mathrm{K}^{-1}\right]$ & 0.133 & 0.132 \\
\hline Kinematic viscosity $\mathrm{u}\left[\mathrm{mm}^{2} \cdot \mathrm{s}^{-1}\right]$ & 17.08 & 17.08 \\
\hline Specific heat $c_{p}\left[J \cdot \mathrm{kg}^{-1} \cdot \mathrm{K}^{-1}\right]$ & 1902 & 2017 \\
\hline Density $\rho\left[\mathrm{kg} \cdot \mathrm{m}^{-3}\right]$ & 867 & 867 \\
\hline Thermal expansion $\beta\left[\mathrm{K}^{-1}\right]$ & 0.00075 & 0.00075 \\
\hline Heat transfer factor $a\left[\mathrm{~W} \cdot \mathrm{m}^{-2} \cdot \mathrm{K}^{-1}\right]$ & 82.35 & 83.26 \\
\hline \multirow{2}{*}{ Property } & \multicolumn{2}{|c|}{ Synthetic ester } \\
\hline & dry & moistened \\
\hline Thermal conductivity $\lambda\left[\mathrm{W} \cdot \mathrm{m}^{-1} \cdot \mathrm{K}^{-1}\right]$ & 0.158 & 0.158 \\
\hline Kinematic viscosity $\mathrm{u}\left[\mathrm{mm}^{2} \cdot \mathrm{s}^{-1}\right]$ & 55.14 & 53.09 \\
\hline Specific heat $c_{p}\left[J \cdot \mathrm{kg}^{-1} \cdot \mathrm{K}^{-1}\right]$ & 1905 & 1975 \\
\hline Density $\rho\left[\mathrm{kg} \cdot \mathrm{m}^{-3}\right]$ & 964 & 964 \\
\hline Thermal expansion $\beta\left[K^{-1}\right]$ & 0.00076 & 0.00076 \\
\hline Heat transfer factor $a\left[\mathrm{~W} \cdot \mathrm{m}^{-2} \cdot \mathrm{K}^{-1}\right]$ & 69.04 & 70.32 \\
\hline \multirow{2}{*}{ Property } & \multicolumn{2}{|c|}{ Natural ester } \\
\hline & dry & moistened \\
\hline Thermal conductivity $\lambda\left[\mathrm{W} \cdot \mathrm{m}^{-1} \cdot \mathrm{K}^{-1}\right]$ & 0.182 & 0.182 \\
\hline Kinematic viscosity $\mathrm{u}\left[\mathrm{mm}^{2} \cdot \mathrm{s}^{-1}\right]$ & 56.29 & 54.96 \\
\hline Specific heat $c_{p}\left[J \cdot \mathrm{kg}^{-1} \cdot \mathrm{K}^{-1}\right]$ & 2028 & 2044 \\
\hline Density $\rho\left[\mathrm{kg} \cdot \mathrm{m}^{-3}\right]$ & 917 & 916 \\
\hline Thermal expansion $\beta\left[\mathrm{K}^{-1}\right]$ & 0.00074 & 0.00073 \\
\hline Heat transfer factor $a\left[\mathrm{~W} \cdot \mathrm{m}^{-2} \cdot \mathrm{K}^{-1}\right]$ & 73.46 & 73.77 \\
\hline
\end{tabular}


Table 4. Measurement results of five thermal properties of the liquids and calculation results of the heat transfer factor a as a function of ageing rate of an insulating liquid; temperature $T=25^{\circ} \mathrm{C}$

\begin{tabular}{|c|c|c|}
\hline \multirow{2}{*}{ Property } & \multicolumn{2}{|c|}{ Mineral oil } \\
\hline & new & aged \\
\hline Thermal conductivity $\lambda\left[\mathrm{W} \cdot \mathrm{m}^{-1} \cdot \mathrm{K}^{-1}\right]$ & 0.133 & 0.133 \\
\hline Kinematic viscosity $\cup\left[\mathrm{mm}^{2} \cdot \mathrm{s}^{-1}\right]$ & 17.08 & 19.09 \\
\hline Specific heat $c_{p}\left[J \cdot \mathrm{kg}^{-1} \cdot \mathrm{K}^{-1}\right]$ & 1902 & 1972 \\
\hline Density $\rho\left[\mathrm{kg} \cdot \mathrm{m}^{-3}\right]$ & 867 & 866 \\
\hline Thermal expansion $\beta\left[\mathrm{K}^{-1}\right]$ & 0.00075 & 0.00075 \\
\hline Heat transfer factor $\mathrm{a}\left[\mathrm{W} \cdot \mathrm{m}^{-2} \cdot \mathrm{K}^{-1}\right]$ & 82.35 & 80.79 \\
\hline \multirow{2}{*}{ Property } & \multicolumn{2}{|c|}{ Synthetic ester } \\
\hline & new & aged \\
\hline Thermal conductivity $\lambda\left[\mathrm{W} \cdot \mathrm{m}^{-1} \cdot \mathrm{K}^{-1}\right]$ & 0.158 & 0.157 \\
\hline Kinematic viscosity $\cup\left[\mathrm{mm}^{2} \cdot \mathrm{s}^{-1}\right]$ & 55.14 & 54.43 \\
\hline Specific heat $c_{p}\left[\mathrm{~J} \cdot \mathrm{kg}^{-1} \cdot \mathrm{K}^{-1}\right]$ & 1905 & 2046 \\
\hline Density $\rho\left[\mathrm{kg} \cdot \mathrm{m}^{-3}\right]$ & 964 & 964 \\
\hline Thermal expansion $\beta\left[\mathrm{K}^{-1}\right]$ & 0.00076 & 0.00076 \\
\hline Heat transfer factor $a\left[\mathrm{~W} \cdot \mathrm{m}^{-2} \cdot \mathrm{K}^{-1}\right]$ & 69.04 & 70.28 \\
\hline \multirow{2}{*}{ Property } & \multicolumn{2}{|c|}{ Natural ester } \\
\hline & new & aged \\
\hline Thermal conductivity $\lambda\left[\mathrm{W} \cdot \mathrm{m}^{-1} \cdot \mathrm{K}^{-1}\right]$ & 0.182 & 0.182 \\
\hline Kinematic viscosity $\cup\left[\mathrm{mm}^{2} \cdot \mathrm{s}^{-1}\right]$ & 56.29 & 60.36 \\
\hline Specific heat $c_{p}\left[\mathrm{~J} \cdot \mathrm{kg}^{-1} \cdot \mathrm{K}^{-1}\right]$ & 2028 & 2012 \\
\hline Density $\rho\left[\mathrm{kg} \cdot \mathrm{m}^{-3}\right]$ & 917 & 917 \\
\hline Thermal expansion $\beta\left[\mathrm{K}^{-1}\right]$ & 0.00074 & 0.00075 \\
\hline Heat transfer factor a $\left[\mathrm{W} \cdot \mathrm{m}^{-2} \cdot \mathrm{K}^{-1}\right]$ & 73.46 & 72.29 \\
\hline
\end{tabular}

synthetic ester, conductivity decreased slightly by $0.6 \%$, whereas for mineral oil and natural ester, it remained at the same level.

Increase of the liquid ageing rate in most cases caused increase of its kinematic viscosity $v$. Mineral oil viscosity increased by $11.8 \%$, natural ester viscosity by $7.3 \%$. By contrast, synthetic ester viscosity decreased slightly by $1.3 \%$.

With an increase of the liquid ageing rate, specific heat $c_{p}$ increased in most of the insulating liquids. Specific heat of mineral oil increased by $3.7 \%$ and of the synthetic ester by $7.4 \%$. By contrast, specific heat of natural ester decreased by $0.8 \%$.

The liquid ageing rate practically had no effect on its density $\rho$. Independently of the liquid kind, density remained at an unchanged level.
The ageing rate did not cause any substantial changes of thermal expansion $\beta$. Expansion of mineral oil and synthetic ester remained at the same level, whereas for natural ester it increased by $1.3 \%$.

The ageing rate of insulating liquid did not affect significantly and explicitly the heat transfer factor $\alpha$. Ageing caused a slight decrease of factor $\alpha$ by $1.9 \%$ for mineral oil and by $1.6 \%$ for natural ester. By contrast, for synthetic ester, ageing caused a slight increase of factor $\alpha$ by $1.8 \%$.

The lack of clear changes of factor $\alpha$ was caused by the fact that with an increase of the liquid ageing rate its kinematic viscosity $\mathrm{v}$ (causing a drop of factor $\alpha$ ) was increasing and simultaneously, its specific heat $c_{p}$ (causing a rise of factor $\alpha$ ) was increasing. This means that liquid ageing practically has no influence on its ability to carry heat away to the surrounding. Viscosity increase was probably caused by the fact that with an increase of the ageing rate, solid products of this process are created. By contrast, increase of specific heat, accompanying liquid ageing resulted from the fact that solid products of this process have higher specific heat than pure insulating liquid.

\section{Conclusions}

The kind of insulating liquid has a considerable influence on its heat transfer factor $\alpha$. It was found on the basis of the research that mineral oil has the highest factor $\alpha$ of the investigated liquids. The esters had factor $\alpha$ lower by over ten percent. It is viscosity of the analyzed liquids, which plays a crucial role. Viscosity of mineral oil was three times lower than viscosity of both kinds of the esters. From the viewpoint of transformer cooling, this means that mineral oil is a more effective liquid in comparison to synthetic or natural ester.

Temperature has significant influence on the heat transfer factor $\alpha$ of the analyzed liquids. A temperature increase from $25^{\circ} \mathrm{C}$ to $80^{\circ} \mathrm{C}$ resulted in an increase of factor $\alpha$ by over $50 \%$ regardless of the liquid kind. It was affected by viscosity, which decreased $5 \div 6$ times with temperature rise, regardless of the liquid kind. This means that the higher the temperature in the transformer the more effectively heat will be carried away to the surrounding by insulating liquid.

Moisture does not have essential significance for the heat transfer factor $\alpha$ in the investigated insulating liquids. Moisture caused an increase of factor $\alpha$ by hardly $2 \%$, regardless of the liquid kind. This rise should be linked with an increase of liquid specific heat by a few percent. That means moisture does not affect transformer cooling conditions.

Liquid ageing does not have explicit influence on the heat transfer factor $\alpha$ of the analyzed liquids. Changes of factor $\alpha$ were hardly $2 \%$. It was on one hand viscosity increase and on the other hand specific heat increase, which were involved. This means that liquid ageing does not have substantial influence on transformer cooling conditions.

\section{References}

1. ABB Inc. Biotemp. Biodegradable dielectric insulating fluid. Product brochure 2009.

2. ASTM D 1903-96. Standard test method for coefficient of thermal expansion of electrical insulating liquids of petroleum origin, and askarels.

3. Borsi H, Gockenbach E. Performance and new application of ester liquids. IEEE 14th International Conference on Dielectric Liquids 2002; 203-206.

4. Borsi H, Gockenbach E, Wasserberg V, Werle P. New devices for a dry type transformer protection and monitoring system. 6th International Conference on the Properties and Applications of Dielectric Materials 2000: 567-570.

5. Borucki S, Boczar T, Cichon A. Investigation of the acoustic pressure distribution occurring around an aerial substation adjacent to apartment buildings. Archives of Acoustics 2007; 32: 291-297.

6. CIGRE Brochure 436. Experiences in service with new insulating liquids. 2010.

7. Cooper Power Industries. Envirotemp FR3 Bulletin 2001; 00092.

8. Feser K, Radakovic Z. A new method for the calculation of the hot-spot temperature in power transformers with ONAN cooling. IEEE Transaction on Power Delivery 2003; 18: 1284-1292, http://dx.doi.org/10.1109/TPWRD.2003.817740. 
9. Gielniak J, Graczkowski A, Morańda H, Przybyłek P, Walczak K, Nadolny Z, Mościcka-Grzesiak H, Feser K, Gubański S M. Moisture in cellulose insulation of power transformers - statistics. IEEE Transactions on Dielectrics and Electrical Insulation 2013; 20: 982-987, http:// dx.doi.org/10.1109/TDEI.2013.6518968.

10. ISO 3104:1994. Petroleum products - Transparent and opaque liquids - Determination of kinematic viscosity and calculation of dynamic viscosity.

11. ISO 3675. Crude petroleum and liquid petroleum products -Laboratory determination of density - Hydrometer method.

12. ISO 649-1:1981. Laboratory glassware - Density hydrometers for general purposes - Part 1: Specification.

13. Koch M, Krueger M, Tenbohlen S. On-site methods for reliable moisture determination in power transformers. IEEE/PES Transmission and Distribution Conference and Exposition 2010: 1-6.

14. Koch M, Tenbohlen S, Rosner M. Moisture ingress in free breathing transformers. International Conference on Condition Monitoring and Diagnosis 2008: 646-650.

15. Łopatkiewicz R, Nadolny Z. Temperature field on high voltage power transformer. Przegląd Elektrotechniczny 2008; 84: 50-52.

16. Łopatkiewicz R, Nadolny Z, Przybyłek P. Influence of water content in paper on its thermal conductivity. Przegląd Elektrotechniczny 2010; 86: 55-58.

17. Łopatkiewicz R, Nadolny Z, Przybyłek P. The influence of water content on thermal conductivity of paper used as transformer windings insulation. IEEE International Conference on the Properties and Applications of Dielectric Materials 2012: 1-4, http://dx.doi.org/10.1109/ icpadm.2012.6318991.

18. Łopatkiewicz R, Nadolny Z, Przybyłek P, Sikorski W. The influence of chosen parameters on thermal conductivity of windings insulation describing temperature in transformer. Przegląd Elektrotechniczny 2012; 88: 126-129.

19. M\&I Materials Ltd. Midel 7131 Synthetic ester transformer fluid. Product guide 2014.

20. Perrier C, Beroual A, Bessede J L. Improvement of power transformers by using mixtures of mineral oil with synthetic esters. IEEE Transactions on Dielectrics and Electrical Insulation 2006; 13: 556-564, http://dx.doi.org/10.1109/TDEI.2006.1657968.

21. Perrier C, Ryadi M, Bertrand Y, Tran Duy C. Comparison between mineral and ester oil. Cigre Session 2010; D1-102: 1-10.

22. Przybyłek P, Nadolny Z, Mościcka-Grzesiak H. Bubble effect as a consequence of dielectric losses in cellulose insulation. IEEE Dielectric and Electrical Insulation 2010; 13: 919-925, http://dx.doi.org/10.1109/tdei.2010.5492266.

23. Suwarno, Darma I S. Dielectric properties of mixtures between mineral oil and natural ester. International Symposium on Electrical Insulating Materials 2008; 514-517.

24. Tenbohlen S, Koch M, Vukovic D, Weinlader A, Baum J, Harthun J, Schafer M, Barker S, Frotscher R, Dohnal D, Dyer P. Application of vegetable oil-based insulating fluids to hermetically sealed power transformers. Cigre Session 2008; A2-102: 1-8.

25. Trnka P, Mentlik V, Svoboda M. The effect of moisture content on electrical insulating liquids. IEEE 18th International Conference on Dielectric Liquids 2014; 1-4, http://dx.doi.org/10.1109/icdl.2014.6893120.

26. Wolny S, Adamowicz A, Lepich M. Influence of temperature and moisture level in paper-oil insulation on the parameters of the Cole-Cole model. IEEE Transaction on Power Delivery 2014; 29: 246-250, http://dx.doi.org/10.1109/TPWRD.2013.2270917.

\section{Grzegorz DOMBEK \\ Zbigniew NADOLNY}

Institute of Electrical Power Engineering

Poznan University of Technology

ul. Piotrowo 3a, 60-965 Poznań, Poland

E-mail: grzegorz.dombek@put.poznan.pl,zbigniew.nadolny@put.poznan.pl 